\title{
Boreal old-growth forest structural diversity challenges aerial photographic survey accuracy
}

\author{
Maxence Martin ${ }^{* 1}$, Hubert Morin ${ }^{1}$, Nicole J. Fenton ${ }^{2}$ \\ ${ }^{1}$ Département des Sciences fondamentales, Université du Québec à Chicoutimi, \\ 555 boul. de l'Université, Chicoutimi, Québec G7H2B1, Canada \\ 2 Institut de Recherche sur les Forêts, Université du Québec en Abitibi- \\ Témiscamingue, 445 boul. de l'Université, Rouyn-Noranda, Québec J9X 5E4, \\ Canada
}

* Corresponding author: Tel.: +1 581882 8651; maxence.martin1@uqac.ca

Keywords: Monitoring, ecosystem-based management, overmature, black spruce, structural attributes, sampling bias, vertical structure, Eastern Canada

Mots-clés: Inventaire, Aménagement écosystémique, suranné, épinette noire, attributs structuraux, biais d'échantillonnage, structure verticale, Est du Canada.

Reference: Martin M, Fenton NJ, Morin H. 2020. Boreal old-growth forest structural diversity challenges aerial photographic survey accuracy. Can J For Res. 50:155-169. doi:dx.doi.org/10.1139/cjfr-2019-0177. 


\begin{abstract}
The erosion of old-growth forests in boreal managed landscapes is a major issue currently faced by forest managers. However, quantifying this phenomenon requires accurate surveys. The intention of our study was to determine if aerial forest surveys accurately identify boreal old-growth forests in Québec, Canada. We first compared stand successional stages (even-aged vs. old-growth) in two aerial surveys performed in 1968 (preindustrial aerial survey) and 2007 (modern aerial survey) on the same $2200 \mathrm{~km}^{2}$ territory. Second, we evaluated the accuracy of the modern aerial survey by comparing its results with those of 74 field plots sampled in the study territory between 2014 and 2016. The two aerial surveys differed significantly; $80.8 \%$ of the undisturbed stands that were identified as "old-growth" in the preindustrial survey were classified as "even-aged" in the modern survey. $60 \%$ of the stands identified as old-growth by field sampling were also erroneously identified as even-aged by the modern aerial survey. The scarcity of obvious old-growth attributes in boreal old-growth forests, as well as poorly adapted modern aerial survey criteria (i.e. criteria requiring high vertical stratification and significant changes in tree species composition along forest succession), were the main factors explaining these errors. It is therefore likely that most of Québec's boreal old-growth forests are currently not recognized as such in forest inventories, which could challenge the effectiveness of sustainable forest management policies.
\end{abstract}

\title{
Résumé
}

L'érosion des superficies des vieilles forêts boréales est actuellement un enjeux majeurs pour les gestionnaires forestier. Répondre efficacemment à cette problématique demande néanmoins l'accès à des données d'inventaires fiables. Ainsi, l'objectif de cette étude était de déterminer si les inventaires forestiers aériens identifient correctement les vieilles forêts dans les paysages boréaux du Québec, Canada. Nous avons comparé les stades de succession (forêt équienne ou vieille forêt) de deux inventaires aériens réalisés en 1968 (inventaire aérien préindustriel) et en 2007 (inventaire aérien moderne) sur un territoire de 2200 
$\mathrm{km}^{2}$. Nous avons aussi comparé les résultats de l'inventaire aérien moderne avec ceux obtenus à partir de 74 placettes de terrain échantillonnés entre 2014 et 2016. Les deux inventaires aériens étaient très incohérents : 80.8\% des peuplements non-perturbés identifiés comme "vieilles forêts » par l'inventaire préindustriel étaient classés comme « équiens » par l'inventaire moderne. $60 \%$ des placettes de terrain identifiées comme vieilles forêts étaient aussi classées « équiens » par l'inventaire aérien moderne. Le manque d'attributs de vieilles forêts évidents ainsi que l'utilisation de critères inadaptés (c'est-à-dire nécessitant une forte complexité verticale et d'importants changements de composition en espèces arborescentes durant la succession forestière) étaient les principaux éléments expliquant ces erreurs. Il est ainsi possible que la majorité des vieilles forêts boréales du Québec ne soient pas identifiés comme telles, limitant l'efficacité des stratégies de gestion durable.

\section{Introduction}

Boreal old-growth forests, i.e. stands driven by gap-dynamics, are defined by specific structural attributes as well as strong temporal continuity due to the absence of stand-replacing disturbances over a significant period (Kneeshaw and Gauthier 2003; Bergeron and Harper 2009; Drapeau et al. 2009a). They contain many habitats features that are absent in younger stands, making them key elements for biodiversity (Tikkanen et al. 2006; Bergeron and Fenton 2012; Boudreault et al. 2018). However, since the middle of the 20th century, industrialscale clear cut harvesting has primarily focussed on the oldest forest stands, leading to a decrease of boreal old-growth forest area all around the circumboreal zone (Östlund et al. 1997; Shorohova et al. 2011; Boucher et al. 2015). Moreover, the short rotation of clearcutting systems, which have been the dominant harvesting approach in boreal forests, inhibits the recruitment of new old-growth stands (Kuuluvainen 2009). Consequently, managed boreal landscapes currently face significant biodiversity issues because of the erosion of the abundance of boreal old-growth forest habitats (Drapeau et al. 2009b; Tikkanen et al. 2006; Patry et al. 2017).

To mitigate the impact of logging on boreal old-growth forests, forest management practices now often aim to maintain remaining boreal old-growth 
forests in managed landscapes or to employ silvicultural treatments that preserve old-growth structural attributes (Bergeron et al. 1999; Bergeron et al. 2002; Bergeron et al. 2007; Bauhus et al. 2009; Gauthier et al. 2009; Drapeau et al. 2009b, Drapeau et al. 2016). To ensure that old-growth habitats in managed landscapes were representative of that present in natural landscapes, an emphasis has been placed on management strategies that are based on natural disturbance regimes or stand scale processes (Gauthier et al. 2009; Kuuluvainen 2009). Yet, boreal old-growth forests are complex and diversified ecosystems. The shift from even-age to old-growth stage does not occur in the same way from one stand to another, varying with tree species, abiotic conditions and secondary disturbance characteristics (Bergeron and Harper 2009; Martin et al. 2018; Martin et al. Accepted). In addition, this shift is not discrete but continuous, making the distinction between the two stages hard to define (Pesklevits et al. 2011). Finally, once the old-growth stage has been reached, boreal old-growth forests continue to exist as structurally diverse and changing ecosystems (Martin et al. 2018; Portier et al. 2018; Moussaoui et al. 2019).

To ensure that remnant boreal old-growth forests are retained during forest harvesting, we have to be able to identify them in forest inventory surveys. These surveys must also be consistent over time in order to evaluate the impacts of forest management. Exhaustive field surveys are not practical in boreal forests because of their vast area. For this reason, aerial photographic surveys are commonly used as a proxy for field surveys. Yet, the efficacy of aerial photographic surveys in identifying structurally complex stands (i.e. old-growth forests) has been challenged based on evidence that such stands can be erroneously classifed as structurally simple (i.e. even-aged) (Boucher et al. 2003; Côté et al. 2010). This implies a potential underestimation of boreal old-growth forest abundance by aerial surveys, which may then limit the efficacy of subsequent management strategies in protecting boreal old-growth stands. Moreover, it is important to assess if this underestimation applies equally to all boreal old-growth forest structures. If not, specific boreal old-growth forest structures may be particularly threatened because they are not well recognized by aerial surveys. 
Boreal old-growth forests are abundant in Québec's unmanaged landscapes because of relatively long (>200 years) fire cycles (Cyr et al. 2005; Grandpré et al. 2009; Bélisle et al. 2011), making Québec an appropriate region to study aerial photographic survey accuracy. In addition, complete aerial photographic surveys of boreal forests have been completed in the province since the end of the 1960s. Industrial scale logging started in the southern edge of the boreal forests in the 1940s and has progressed northward since (Boucher et al. 2017). Thus, the first surveys often inventoried landscapes where anthropogenic influences were almost inexistent, i.e. preindustrial landscapes. Our study therefore aimed to determine if aerial forest surveys accurately identify boreal old-growth forest in Québec's landscapes dominated by black spruce - feather moss forests, the main closedforest type in Québec's boreal territories (Rowe 1972). Specifically, our objectives were: (1) to determine if old-growth stands are consistently identified by aerial surveys over time, (2) to evaluate the accuracy of the most recent aerial survey in identifying different boreal old-growth forest types, and (3) to identify oldgrowth types that are the most likely to be confused with even-aged stands. We expected that the accuracy of the aerial photographic surveys increased over time and thus most of the old-growth forests would be accurately identified by the most recent survey. However, we also predict that stands at the beginning of the old-growth stage will be those most commonly mistaken for even-aged stands because of the absence of any clear transition between the two stages. This study evaluates the accuracy of aerial photographic surveys, first by discriminating even-aged and old-growth stands and second by identifying how well the entire structural diversity of boreal old-growth forest developemental stages is determined. We discuss how efficient is the photographic survey approach to integrate boreal old-growth forests in managed landscapes and what are the potential biases and errors.

\section{Methods}

Study area and field sampling

In this study we used the same $2200 \mathrm{~km}^{2}$ area described by Martin et al. (2018) and Martin et al. (Accepted), situated to the south east of Lake Mistassini $\left(72^{\circ} 15^{\prime} 00^{\prime \prime} \mathrm{W}\right.$ to $72^{\circ} 30^{\prime} 00^{\prime \prime} \mathrm{W}, 50^{\circ} 07^{\prime} 23^{\prime \prime} \mathrm{N}$ to $\left.50^{\circ} 30^{\prime} 00^{\prime \prime}\right)$ (Figure 1). This 
Preprint Martin et al. (2020) Boreal old-growth forest structural diversity challenges aerial photographic survey accuracy. Can J For Res. 50:155-169.

territory is public land and part of the black spruce (Picea mariana (Mill.)) feather moss bioclimatic domain. Black spruce and balsam fir (Abies balsamea (L.) Mill.) are the dominant tree species. They are sometimes found with jack pine, (Pinus banksiana (Lamb.), white spruce (Picea glauca (Moench) Voss), paper birch (Betula papyrifera Marsh.) and trembling aspen (Populus tremuloides). The dominant surface deposits are thick glacial tills but watercourses are often surrounded by sand deposits or vast bogs. The topography of

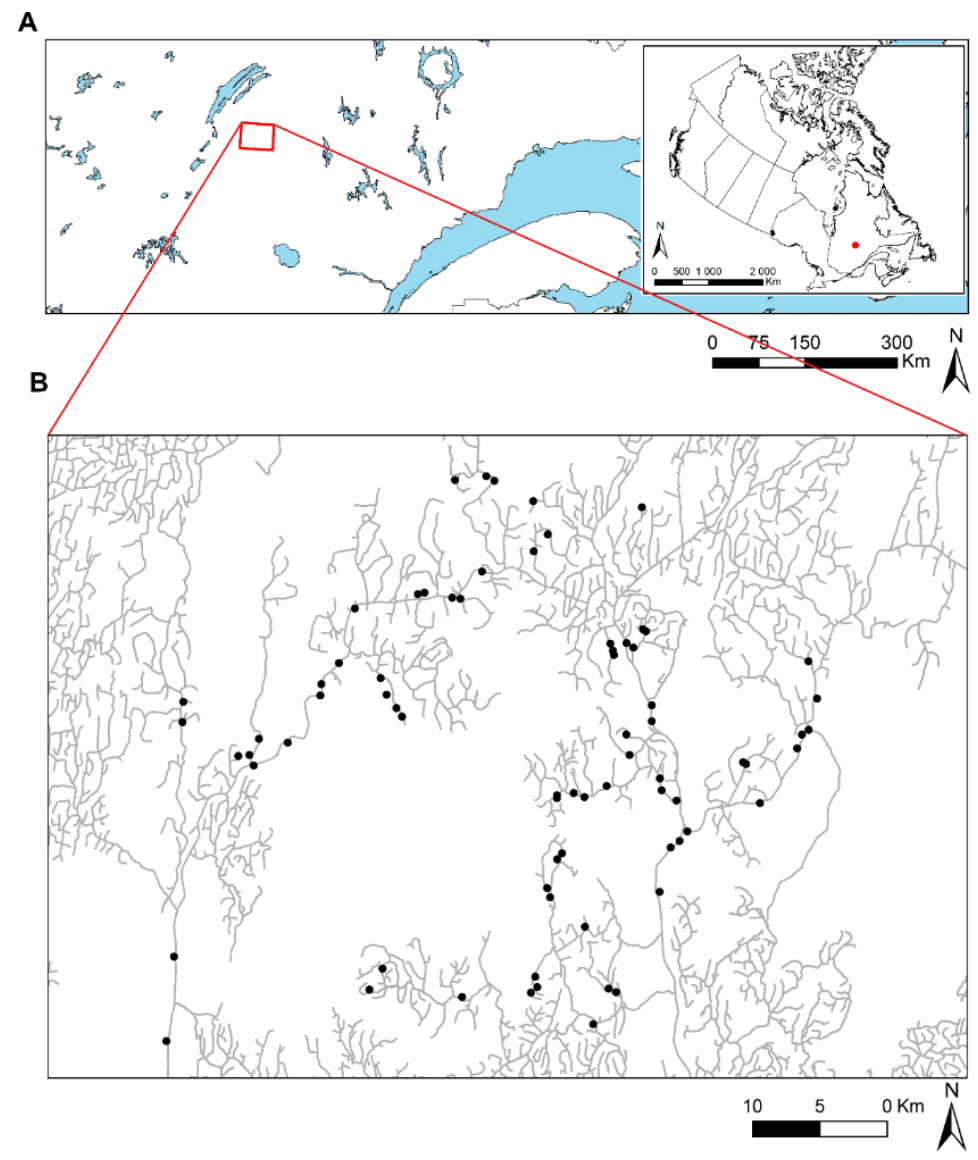

Figure 1 (A) Location of the study territory (red rectangle) in the province of Québec. The red dot in the insert map indicates its location in Canada. (B) Field plots (black dots) sampled in the study territory. Grey lines represent the forest road network. 
the study territory is dominated by gentle hills with altitudes ranging from 350 to $750 \mathrm{~m}$. Mean annual temperature ranges from -2.5 to $0.0^{\circ} \mathrm{C}$, annual rainfall (rain and snow) from 900 to $1100 \mathrm{~mm}$ and growing season length is from 140 to 150 days (Robitaille and Saucier 1998). Timber exploitation started in 1991 at a low level until the year 2000, when harvest levels increased. Consequently, all surveys performed on this territory before 1991 represent forests free from any industrial logging activity

Martin et al. (2018) and Martin et al. (Accepted) surveyed 74 stands between 2014 and 2016 on this territory (Figure 1). Stand selection was based on stratified random sampling of the six dominant environmental types on the study territory, as defined by Québec's Ministry of Forests, Wildlife and Parks (MFWP) ecological classification (Blouin and Berger 2004), and two stand minimal age classes. The dominant environmental types can be defined by the following Potential vegetation/Slope/ Superficial deposit/Drainage associations: Balsam fir - white birch/Medium/Till/ Mesic; Black spruce balsam fir/Medium/Till/Mesic; Black spruce - feather moss (BSFM)/Low/Sand/Mesic; BSFM/Low/Till/Mesic; BSFM/ Low/Till/Subhydric; BSFM/Low/Organic/Hydric. These represent over $72 \%$ of productive forest area on the study territory. The age classes corresponded to the theoretical stages of the transition process toward the old-growth stage in Québec boreal forests: 80-200 years (beginning of the transition) and greater than 200 years (end of the transition). Site age was assessed by a preliminary survey through tree core sampling of five dominant and codominant trees per site. Only sites accessible by road were selected and plots were systematically placed $125 \mathrm{~m}$ away from the stand edge to limit edge effects.

In each stand we collected data on: merchantable trees (diameter at breast height [dbh] $\geq 9 \mathrm{~cm}$ ), saplings (trees with a $\mathrm{dbh}<9 \mathrm{~cm}$ and a height $>1.30 \mathrm{~m}$ ), gap fraction and coarse woody debris volume using one $400 \mathrm{~m}^{2}$ plot with nested subplots and transects (see Table 1 for details). To determine the minimum stand age, we performed a destructive sampling of basal discs on ten trees. Sampled trees were randomly selected according to their crown class (dominant, codominant, intermediary and suppressed). At least three of these trees were dominant trees and their height was measured once the tree was felled to estimate the maximum stand height. Two or three trees were then sampled for each of the 
Preprint Martin et al. (2020) Boreal old-growth forest structural diversity challenges aerial photographic survey accuracy. Can J For Res. 50:155-169.

remaining crown classes, depending on their availability within the plot. The sampled basal discs were then sanded and the tree rings measured along two radii to determinate tree age.

Table 1 Description of the sampling design and the attributes sampled for each type of data studied in field plots.

Data

\begin{tabular}{ll}
\hline & \\
$\begin{array}{l}\text { Merchantable } \\
\text { trees }\end{array}$ & $\begin{array}{l}\text { All individuals in one } 20 \times 20 \mathrm{~m}\left(400 \mathrm{~m}^{2}\right) \text { square } \\
\text { plot }\end{array}$
\end{tabular}

\section{Attributes sampled}

Diameter at breast height, species, vitality (alive, senescent, dead) and position in the canopy as de by the Québec's Ministry of Wildlife, Fauna and Parks typology (MRNF 2008):

- Dominant: highest trees in the stand

- Codominant: height $\geq 2 / 3$ of dominant tree heig - Intermediary: height $<2 / 3$ and $\geq 1 / 2$ of dominan height

- Suppressed: height $<1 / 2$ of dominant tree heigr

\begin{tabular}{lll}
\hline Saplings & $\begin{array}{l}\text { All individuals in two } 10 \times 10 \mathrm{~m}\left(100 \mathrm{~m}^{2}\right) \text { square } \\
\text { plots within the } 400 \mathrm{~m}^{2} \text { plot }\end{array}$ & Diameter at breast height, species \\
\hline
\end{tabular}

All gaps along five $25 \mathrm{~m}$ long transects starting from the centre of the $400 \mathrm{~m}^{2}$ plot. "Gaps" were all

Gap fraction sections of the transects where the canopy height was less than the $2 / 3$ rds of the height of the dominant trees for a distance of $>2 \mathrm{~m}$ along the transect
Gap length
All coarse woody debris that intersected four $20 \mathrm{~m}$

Coarse woody long transects that followed the edge of the $400 \mathrm{~m}^{2}$

debris (CWD) plot. When a piece of CWD crossed two transects, any second encounter was skipped to avoid doublecounting.

\section{Cartographic data}

The government of Quebec has conducted five decadal forest surveys; the fifth survey is still in progress. All these inventories use aerial photographs to describe forest stands. We chose to focus on the results of the first (preindustrial aerial survey) and the fourth (modern aerial survey) decadal forest inventories, because they represent the two extremes in terms of technological evolution over the time period. On our study area, 1/15 000 aerial photographs were taken at an average altitude of 2 295m in 1968 for the preindustrial aerial survey (black and white photographs) and in 2007 for the modern aerial survey (high definition numeric 
false-colour infrared photographs). For both surveys, the boundaries of forest stands were defined according to their cartographic structural characteristics (tree species composition, age, structural complexity, height and density classes) and abiotic characteristics (slope, drainage, superficial deposit and potential vegetation classes). These characteristics were interpreted by stereoscopic photointerpretation with the help of topographic maps for the preindustrial aerial survey or a stereoscopic analysis software for the modern. The MFWP then simplified stand boundaries for the preindustrial survey only: the territory was divided in $297 \mathrm{~m} \times 463 \mathrm{~m}$ large rectangles (15 seconds x 15 seconds in geographic coordinates, 14ha) named "tessels" (Appendix A). The cartographic structural and abiotic values attributed to each tessel were the characteristics of the preindustrial forest stand polygon situated at the tessel centroid location. Preindustrial and modern aerial surveys can therefore be compared along the tessel grid, where each centroid represents the results of both forest surveys at the centroid location.

\section{Identification of the old-growth stages}

Based on Martin et al. (2018), the old-growth stage starts when new cohorts begin to replace the first cohort or when the tree diameter distribution shifts from a Gaussian to an irregular diameter distribution. However, field and cartographic data, as well as preindustrial and modern aerial surveys, use different parameters to describe stand structural complexity. Therefore, a preliminary analysis was necessary to homogenise the descriptors of stand structural complexity in order to identify old-growth stands for both field and cartographic data.

For field data, we identified the old-growth stages using the methodology of Martin et al. (2018). First, we fitted the diameter distribution of all merchantable stems and saplings in each plot with the Weibull distribution (Bailey and Dell 1973). A Weibull's shape parameter (WSP) $\geq 1.5$ indicates a normal diameter distribution and a WSP $<1.5$ indicates an irregular diameter distribution. Second, we counted tree rings along two radii for each of the ten basal discs sampled and the maximum value was considered as the minimum age of the tree. We identified the cohort of the trees for each stand. If the age difference between 
the youngest and the oldest tree did not exceed 30 years, we considered that they were all first cohort trees. If some trees exceeded the 30-year threshold, we considered these trees as belonging to old-growth cohorts replacing the first cohort. In this case, we looked for evidence of suppression on juvenile trees in the trees under the 30-year threshold (i.e. sustained low radial increment starting from the pith). Trees that presented no evidence of juvenile suppression were categorized as first cohort trees while the others were categorized as old-growth cohort trees. Finally, when the majority of the trees belonged to a single 30-year age class but were mixed with individuals more than 30 years older, the older individuals were considered as survivors of the previous stand-initiating disturbance and removed from the analysis. The remaining trees were classified as first cohort trees. Then, we calculated the Cohort Basal Area Ratio (CBAP) according to the Kneeshaw and Gauthier (2003) formula:

$$
C B A P=\frac{\left(B A_{\text {old-growth cohort trees }}+0.1\right)}{\left(B A_{\text {old }- \text { growth cohort trees }}+B A_{\text {First cohort trees }}+0.1\right)}
$$

where $B A$ is the basal area. Stands were defined as even-aged if WSP $\geq 1.5$ and $\mathrm{CBAP}<0.3$ and old-growth in all other cases (Martin et al. 2018). For each field plot, we also computed the eight following field structural attributes: tree density, basal area, sapling density, balsam fir proportion, coarse woody debris volume, gap fraction, maximum height, merchantable trees' Shannon Index and minimum time since the last fire (i.e. age of the oldest tree sampled) (Appendix B).

For cartographic data from the modern aerial survey, stand structure was classified in one class among four (even-aged, uneven-aged, irregular and layered classes, MRNF 2008), based on cohort composition and stand vertical structure, estimated during photo-interpretation. We considered that the uneven-aged, irregular and layered classes indicated old-growth forests because their complex vertical structure and/or the presence of different cohorts implied gap-dynamics (Table 2). In contrast, in the preindustrial aerial survey data, there were only two stand structure classes for the mature plots: "Regular" and "Irregular" (Pelletier et al. 2007), also estimated by photo-interpretation. Therefore, we assumed the "Regular" class to be "Even-aged" while the "Irregular" class was assumed to be "Old-growth". The cartographic structural attributes computed 
for the analyses were: preindustrial dominant species, preindustrial and modern canopy densities, modern and preindustrial tree height, modern black spruce abundance (i.e. black spruce proportion in stand canopy), modern balsam fir abundance, modern jack pine abundance, modern broadleaved species abundance (Appendix C), using the classes defined by the MFWP.

Table 2 Characteristics of the different age structures classes used by the preindustrial and modern surveys and of the developmental stage extrapolated (even-aged or old-growth) for this study

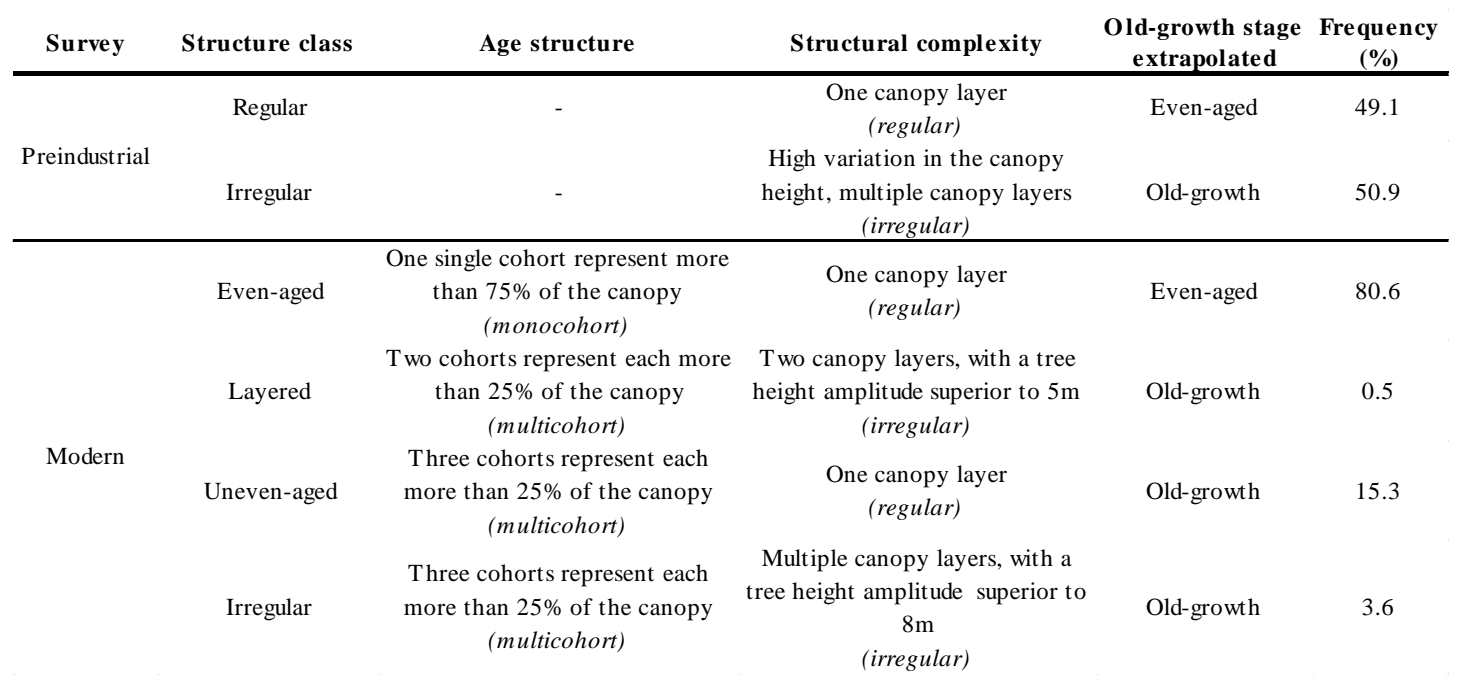

\section{Statistical analysis}

For our first objective, to determine if old-growth stands are consistently identified by aerial surveys over time, we compared the classification of stands in the two time periods (preindustrial and modern) using the 3417 undisturbed, mature centroids. We computed the error-matrix and the overall accuracy (proportion of the centroids or field plots mapped correctly) of the even-aged and old-growth stands in the preindustrial and modern aerial surveys using the Olofsson et al. (2013) methodology. Yet, forests are dynamic ecosystems and their structure may change over time, however as we selected only undisturbed sites, the main consistent structural change should be a shift from the even-aged to the old-growth stage. In contrast, any shift from the old-growth stage to the evenaged in the absence of any natural stand-replacing disturbance or logging activities is unlikely and would be the result of errors in old-growth identification 
in at least one of the aerial surveys. Then, we used logistic regressions to determine if centroids presenting these erroneous dynamics were the result of a specific bias. The classes of the dependent dummy variables were "Consistent dynamics" (same stage between the two surveys or shift from the even-aged stage to the old-growth) and "Inconsistent dynamics" (shift from old-growth to evenaged). We selected as independent variables only the cartographic structural attributes that were not associated with each other based on the $\varphi$ or Cramer's $\mathrm{V}$ values (Sheskin 2002). If a strong association between two attributes was caused by low-abundant classes, we removed the sites defined by these classes from the dataset. Thus, centroids belonging to the " $>80 \%$ " preindustrial or modern canopy density classes were strongly associated with each other but they only represented 255 centroids. We therefore removed these sites from the final dataset $(255$ centroids removed from the analysis, total remaining $=3162)$. The independent variables retained for the logistic regression were preindustrial canopy density, modern balsam fir abundance and modern canopy tree density. The model was run a first time with all the variables and a second time with only the significant variables, in order to obtain the most parsimonious model. Then, we used log-likelihood test, Receiver Operating Characteristic (ROC) (Zweig and Campbell 1993) and Tjur's coefficient of discrimination (COD, Tjur 2009) to assess the model predictive ability.

For our second objective, evaluating the accuracy of the most recent aerial survey in identifying different boreal old-growth forest cover types, we compared the age structure (monocohort or multicohort), the diameter distribution (regular or irregular) and the old-growth stage (even-aged or old-growth) of the 74 field plots based on our field inventories with the results of the typology of the recent survey.. Error-matrixes were computed and the overall accuracies (proportion of the area mapped correctly) were calculated for each matrix. In addition, we compared the differences in field-sampled structural attributes according to the accuracy of the modern aerial survey in identifying their age structure, structural complexity or old-growth stage (Identical: same result between field and aerial surveys; Different: different result between field and aerial surveys). Student tests were used to assess the statistical significance of these differences between surveys if requirements (homoscedasticity and normality of the independent variable for each group) were fulfilled, otherwise we used the Wilcoxon test. Four field plots 
belonged to the "unproductive" class in the modern aerial survey were not assigned to structural complexity or age structure classes. These sites were removed for this analysis, leaving 70 fields plots.

Finally, for our third objective, to identify old-growth types that are more likely to be confused with even-aged stands, we aimed to discriminate the vertical structure of the sampled stands based on the structural parameters that challenged aerial survey accuracy. First, we determined the proportion of trees from each crown class (dominant, codominant, intermediate and suppressed) in each plot. Then, we performed a multivariate regression tree analysis (De'ath 2002) with 100 repetitions using the structural parameters having a significant impact on survey accuracy in the previous analyses (logistic regression, Student or Wilcoxon tests). We considered that balsam fir proportion in basal area, gap fraction and maximum height computed for the field plots corresponded to the respective attributes computed for aerial surveys: modern balsam fir abundance, modern canopy density (inverse of the gap fraction) and modern stand height. We selected the optimal regression tree based on the best balance between a low relative error and a limited number of groups. This analysis was performed using only the field plots sampled in 2015 and 2016 identified as productive by the modern aerial survey (67 plots), as some field structural attributes were missing for the field plots sampled in 2014. We then computed old-growth stage errormatrixes and overall accuracies between modern aerial and field surveys for each cluster.

All the statistical analyses were performed using R-software, version 3.3.1 (R Development Core Team 2016), using the fmsb (Nakazawa 2017), ROCR (Sing et al. 2005), sjstats (Lüdecke 2018), vegan (Oksanen et al. 2018) and mvpart (Therneau and Atkinson 2014) packages. A p-threshold of 0.05 assess the tests significance.

\section{Results}

\section{Comparison of the aerial surveys}

Nearly fourty percents of the centroids (40.9\%) presented an even-aged structure in both aerial surveys (Table 3). Yet, 39.7\% of the plots showed an inconsistent 
structural evolution, i.e., an old-growth structure in the preindustrial aerial survey and an even-aged structure in the modern aerial survey. Hence, $80.1 \%$ of the undisturbed centroids identified as old-growth in the preindustrial survey were identified as even-aged in the modern. The remaining old-growth stage combinations were less abundant (10\% shifted from even-aged to old-growth and $9.4 \%$ of centroids were stable old-growth centroids). The strong changes between the two surveys ( $49.7 \%$ of the plots presenting a different structure) resulted in a low overall accuracy (50.3\%) and most of these changes were inconsistent with natural forest dynamics in the absence of any stand-replacing disturbance. This implied a significant bias in at least one of the aerial surveys.

Table 3 Error-matrix between the preindustrial and modern aerial surveys. Bold results refer to inconsistent structural evolution, i.e. the shift from old-growth to even-aged between the preindustrial and modern aerial surveys in the absence of any stand-replacing disturbance.

\begin{tabular}{lrrrrrrr} 
& \multicolumn{2}{c}{$\begin{array}{c}\text { Preindustrial survey } \\
\text { Modern survey }\end{array}$} & \multicolumn{3}{c}{$\begin{array}{c}\text { Even-aged matrix } \\
\text { Orror-growth }\end{array}$} & Total & \multicolumn{2}{c}{ Even-aged } & Old-growth Total & \multicolumn{2}{c}{$\begin{array}{c}\text { Overall } \\
\text { accuracy }\end{array}$} \\
\hline Even-aged & 1398 & $\mathbf{1 3 5 6}$ & 2754 & 40.9 & 39.7 & 80.6 & 50.3 \\
Old-growth & 342 & 321 & 663 & 10.0 & 9.4 & 19.4 & \\
Total & 1740 & 1677 & 3417 & 50.9 & 49.1 & 100.0 &
\end{tabular}

All the explanatory variables of the logistic regression model comparing centroid structural evolution between the surveys (i.e. consistent or inconsistent) were significant (Appendix D). In addition, the model presented a good predictive ability, with a $\mathrm{ROC}=0.71$ and a $\mathrm{COD}=0.14$. The parameters associated with inconsistent structural evolution were: lower modern abundance of balsam fir, generally lower pre-industrial canopy density and higher modern canopy density. Although balsam fir was present in more than $25 \%$ of the centroids showing a consistent structural evolution, this species was almost absent in the plots with an inconsistent structural evolution (Figure 2). Furthermore, centroids presenting a consistent structural evolution mainly belonged to the preindustrial canopy density class [60\%-79.9\%]. In contrast, centroids defined by an inconsistent structural evolution mainly belonged to the preindustrial canopy 
density classes [25\%-39.9\%] and [40\%-59.9\%]. Centroids belonging to the modern canopy density classes [60-79.9\%] were more abundant in the inconsistent structural evolution group in comparison to consistent structural evolution group. Yet, differences in modern canopy density according to the structural evolution were less striking than those observed for the preindustrial canopy density. Therefore, stands that shifted from the old-growth to the even-aged stage between the two surveys are mostly pure black spruce stands with a sparse canopy.
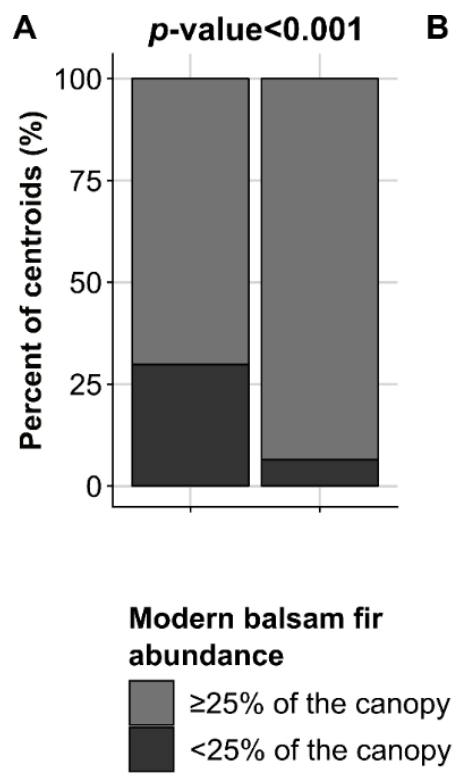

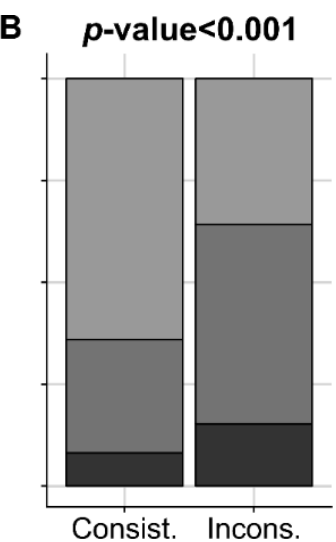

Evolution

Preindustrial canopy density [60\%-79.9\%] [40\%-59.9\%] [25\%-39.9\%]
C $p$-value $<0.001$

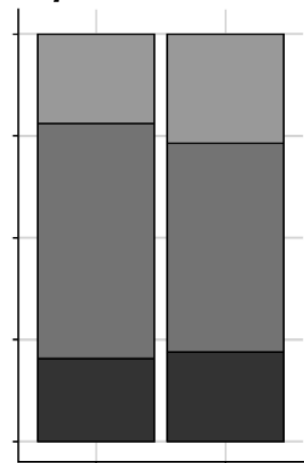

Modern canopy density

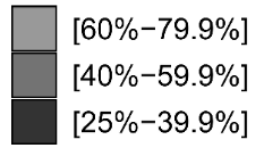

Figure 2 Histogram of the class distribution and $p$-value of the significant parameters according to the logistic regression model comparing centroids defined by a consistent or an inconsistent structural evolution, separated depending on the binary dependant variable: (A) Modern balsam fir abundance, (B) Preindustrial tree density, (C) Modern tree density. Consist.: consistent structural evolution; Incons.: Inconsistent structural evolution. Consistent structural evolution refers to the same stage between the two surveys or shift from the even-aged stage to the old-growth between the preindustrial and modern aerial surveys. Inconsistent refers to shift from old-growth to even-aged between the preindustrial and modern surveys. The characteristics of the independent variables' classes are presented in Appendix B. 


\section{Comparison of cartographic survey with field survey}

The modern aerial survey was more accurate in discriminating monocohort and multicohort stands (Overall accuracy $=56 \%$, Table 4A) than regular and irregular stands (Overall accuracy $=21.4 \%$, Table $4 \mathrm{~B}$ ), even if all these results were low. As a consequence, the modern aerial survey failed to correctly identify the successional stage for half of the field plots (Overall accuracy $=44 \%$, Table $4 \mathrm{C})$. This error was specifically related to old-growth stands, as $40 \%$ of the oldgrowth field plots were

Table 4 Error-matrixes between the field and modern aerial surveys for stand (A) structural complexity, (B) age structure and (C) oldgrowth stage.

A

\begin{tabular}{|c|c|c|c|c|c|c|c|}
\hline \multirow[b]{2}{*}{ Modern survey } & \multicolumn{3}{|c|}{ Field plots } & \multicolumn{3}{|c|}{ Error Matrix } & \multirow{2}{*}{$\begin{array}{l}\text { Overall } \\
\text { accuracy }\end{array}$} \\
\hline & Regular & Irregular & Total & Regular & Irregular & Total & \\
\hline Regular & 7 & 55 & 62 & 10.0 & 78.6 & 88.6 & 21.4 \\
\hline Irregular & 0 & 8 & 8 & 0.0 & 11.4 & 11.4 & \\
\hline Total & 7 & 63 & 70 & 10.0 & 90.0 & 100.0 & \\
\hline
\end{tabular}

B

Field plots

Error Matrix

Overall

\begin{tabular}{llllllll} 
Modern survey & Monocohort & Multicohort & Total & Monocohort & Multicohort & Total & accuracy \\
\hline Monocohort & 17 & 27 & 44 & 24.3 & 38.6 & 62.9 & 55.7 \\
Multicohort & 4 & 22 & 26 & 5.7 & 31.4 & 37.1 & \\
Total & 21 & 49 & 70 & 30.0 & 70.0 & 100.0 &
\end{tabular}

C

\begin{tabular}{|c|c|c|c|c|c|c|c|}
\hline \multirow[b]{2}{*}{ Modern survey } & \multicolumn{3}{|l|}{ Field plots } & \multicolumn{3}{|c|}{ Error Matrix } & \multirow{2}{*}{$\begin{array}{l}\text { Overall } \\
\text { accuracy }\end{array}$} \\
\hline & Even-aged & Old-growth & Total & Even-aged & Old-growth & Total & \\
\hline Even-aged & 5 & 39 & 44 & 7.1 & 55.7 & 62.9 & 44.2 \\
\hline Old-growth & 0 & 26 & 26 & 0.0 & 37.1 & 37.1 & \\
\hline Total & 5 & 65 & 70 & 7.1 & 92.9 & 100.0 & \\
\hline
\end{tabular}


Preprint Martin et al. (2020) Boreal old-growth forest structural diversity challenges aerial photographic survey accuracy. Can J For Res. 50:155-169.

Table 5 Mean values, standard deviation (in italics) and $p$-values, based on the Student or Wilcoxon test of the structural parameters of the field plots between those for which the diameter structure or the age structure have been correctly identified (identical) by the modern aerial survey and those incorrectly identified (different). The absence of values in the $p$-value column indicates a non-significant result. TD: Tree density (n/ha), BA: basal area $\left(\mathrm{m}^{2} / \mathrm{ha}\right)$, BFP: balsam fir proportion (\%), WSP: Weibull's shape parameter, GF: Gap fraction (\%), CWD: Coarse woody debris volume $\left(\mathrm{m}^{3} / \mathrm{ha}\right)$, MH: Maximum height (m), SD: Sapling density (n/ha), SIMT: Shannon Index of the merchantable trees, CBAP: Cohort Basal Area Proportion, MTSLF: Mean time since last fire (years).

\begin{tabular}{|c|c|c|c|c|}
\hline \multirow{2}{*}{ Variable } & \multirow{2}{*}{$\begin{array}{l}\text { Structural } \\
\text { parameter }\end{array}$} & \multicolumn{2}{|c|}{ Similarity between field and aerial surveys } & \multirow{2}{*}{$p$-value } \\
\hline & & Identical & Different & \\
\hline \multirow{11}{*}{$\begin{array}{l}\text { Structural } \\
\text { complexity } \\
(n \text { identical }=15 \text {; } \\
n \text { different }=55)\end{array}$} & TD & $996.66 \pm 465.3$ & $932.27 \pm 349.55$ & \\
\hline & BA & $20.61 \pm 8.39$ & $17.46 \pm 6.77$ & \\
\hline & BFP & $0.12 \pm 0.16$ & $0.13 \pm 0.23$ & \\
\hline & WSP & $1.41 \pm 0.7$ & $0.93 \pm 0.26$ & \\
\hline & GF & $52.82 \pm 25.29$ & $62.96 \pm 24.39$ & \\
\hline & CWD & $75.57 \pm 71.09$ & $57.73 \pm 45.97$ & \\
\hline & MH & $19.51 \pm 3.21$ & $18.59 \pm 2.76$ & \\
\hline & SD & $2506.66 \pm 2322.58$ & $2670.45 \pm 1877.11$ & \\
\hline & SI & $0.22 \pm 0.14$ & $0.12 \pm 0.12$ & $<0.05$ \\
\hline & CBAP & $0.4 \pm 0.36$ & $0.62 \pm 0.34$ & $<0.05$ \\
\hline & MTSLF & $180.00 \pm 65.88$ & $202.07 \pm 60.76$ & \\
\hline \multirow{11}{*}{$\begin{array}{l}\text { Age } \\
\text { Structure } \\
(\text { n identical }=39 ; \\
n \text { different }=31)\end{array}$} & TD & $892.94 \pm 355.12$ & $1012.9 \pm 393.16$ & \\
\hline & $\mathrm{BA}$ & $18.31 \pm 7.28$ & $17.9 \pm 7.21$ & \\
\hline & BFP & $0.16 \pm 0.24$ & $0.09 \pm 0.18$ & \\
\hline & WSP & $1.06 \pm 0.52$ & $1.00 \pm 0.3$ & \\
\hline & GF & $57.33 \pm 27.15$ & $64.92 \pm 21.31$ & \\
\hline & CWD & $66.18 \pm 54.81$ & $55.72 \pm 49.18$ & \\
\hline & $\mathrm{MH}$ & $19.03 \pm 3.03$ & $18.48 \pm 2.64$ & \\
\hline & SD & $2502.56 \pm 1991.56$ & $2802.41 \pm 1947.96$ & \\
\hline & SI & $0.18 \pm 0.14$ & $0.09 \pm 0.11$ & $<0.01$ \\
\hline & CBAP & $0.5 \pm 0.38$ & $0.66 \pm 0.3$ & \\
\hline & MTSLF & $183.76 \pm 60.03$ & $214.41 \pm 61.3$ & $<0.05$ \\
\hline
\end{tabular}


identified as such by the modern survey, while all the even-aged field plots were accurately identified. Overall, the modern aerial survey tended to overestimate the abundance of even-aged stands on the landscape. The field structural attributes that explained the errors in the identification of the structural complexity classes in the modern aerial survey were the Shannon Index of the merchantable trees and the cohort basal area proportion (Table 5). For the age structure, the Shannon Index of the merchantable trees and the minimum time since the last fire were the parameters that best explained age structure errors. Sites erroneously identified, for both age structure and structural complexity, had a lower Shannon Index of the merchantable trees but an equivalent balsam fir proportion value, indicating that other species than balsam or black spruce (e.g. jack pine, white birch, aspen or white spruce) may have influenced these results. In addition, the progressive replacement of the first cohort, defined by the cohort basal area proportion, or the stand age, defined by the minimum time since the last fire, had different influence on modern survey accuracy. Indeed, cohort basal area proportion was only significantly different for structural complexity, while the minimum time since the last fire was only significantly different for the age structure. It suggests that these processes have different impacts on stand structure and thus caused different errors in the modern survey. Overall, older monospecific stands dominated by old-growth cohorts were more likely to be inaccurately categorized than younger stands where the first cohort was still dominant and/or where tree diversity was higher.

Which boreal old-growth structures are less accurately classified by the modern aerial survey?

Based on the results of the logistic regression and of the Wilcoxon or Student tests, balsam fir proportion, gap fraction, Shannon Index of the merchantable trees, CBAP and minimum time since the last fire were the main field structural attributes selected to construct the multivariate regression tree. The optimal tree was divided into 5 clusters (Figure 3), where CBAP is the first cut-off factor (threshold value $=0.2$ ), balsam fir proportion the second (threshold value $=$ $2.57 \%$ for clusters 1-4) and gap fraction the third (threshold value $=49.4 \%$ for clusters 1-2 and threshold value $=72.4 \%$ for clusters $3-4$ ). 
Cluster 1 contained most of the mixed black spruce - balsam old-growth stands and was defined by a high gap fraction. The majority of the merchantable trees belonged to the suppressed crown class. All field plots were old-growth and around half of them were accurately identified as such by the modern aerial survey in this cluster (Overall accuracy $=52.9 \%$, Table 56). Cluster 2 contained the remaining mixed black spruce - balsam old-growth stands, with a lower gap fraction than cluster 1. Again, all field plots were old-growth. Suppressed trees still dominated the canopy but trees from the other layers were more abundant in comparison to cluster 1 . This cluster was better identified by the aerial survey as being old-growth (Overall accuracy $=66.7 \%$ ). Cluster 3 contained a small part of the pure black spruce old-growth stands and was defined by the highest gap fraction among the clusters. The vertical structure of cluster 3 was intermediate between cluster 1 and cluster 2. Less than one-third of the field plots belonging to this cluster were accurately classified by the modern aerial survey (Overall accuracy $=28.6 \%$ ). Cluster 4 included most of the pure black spruce old-growth stands, with a lower gap fraction compared to cluster 3. In contrast to the previous clusters, trees from the intermediate crown class were dominant in cluster 4, while suppressed and codominant trees were present in similar proportions. Around one fifth of the field plots were accurately classified by the modern aerial survey in this cluster (Overall accuracy $=21.1 \%$ ). Finally, cluster 5 contained stands at the beginning of old-growth transition, including those containing a small proportion of balsam fir. The vertical structure of cluster 5 differed from those of the previous clusters, as trees belonging to the codominant crown class were more frequent. All the even-aged stands and more than one third of the old-growth stands were accurately identified by the modern aerial survey (Overall accuracy $=46.7 \%$ ). 


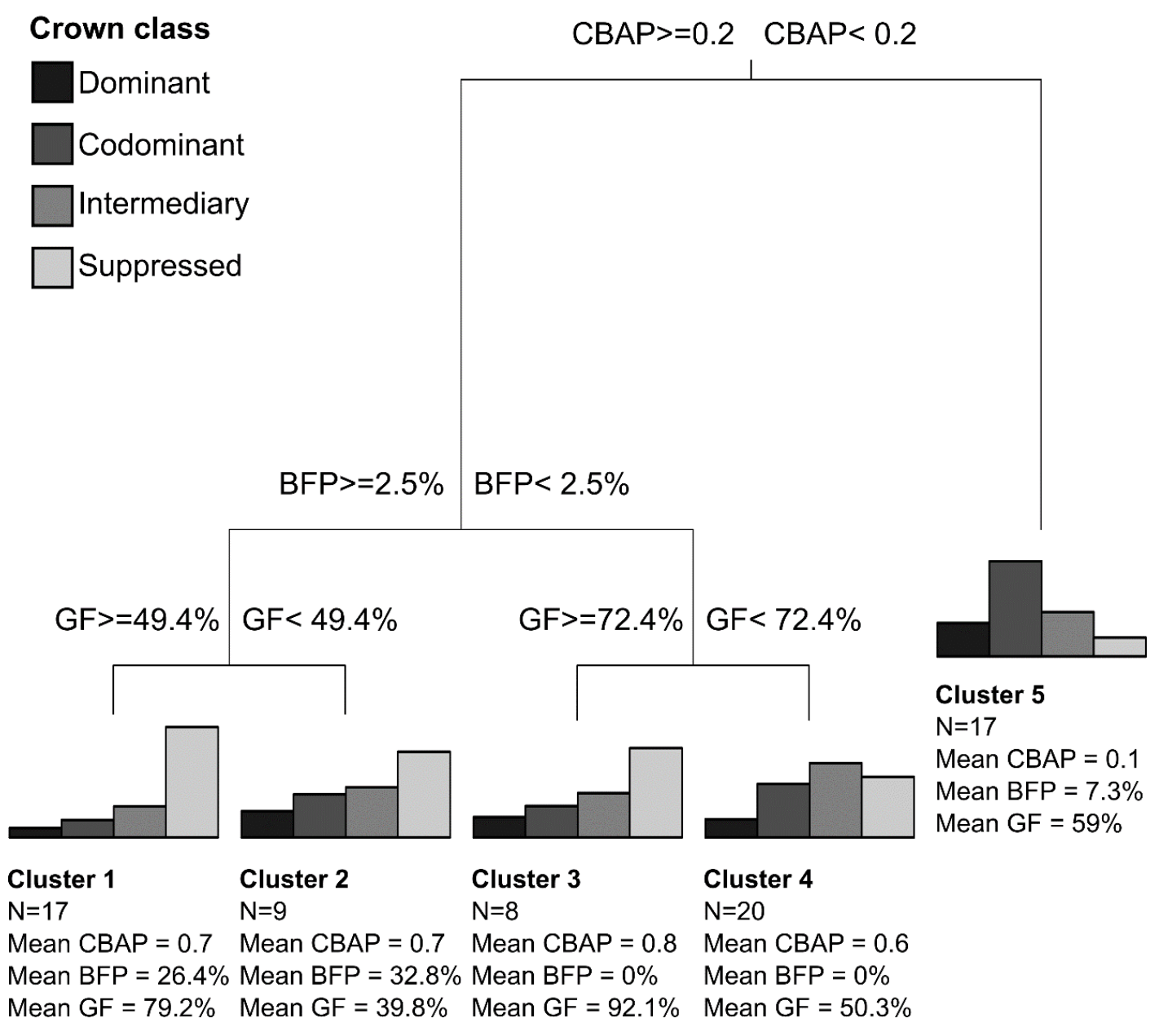

Figure 3 Dendrogram of the multivariate analysis performed on the distribution of the canopy layers in the field plots. Histogram represent the mean frequency of the canopy layers category in each class. CBAP: Cohort Basal Area Ratio, BFP: Balsam fir proportion (\%), GF: Gap fraction (\%). 
Preprint Martin et al. (2020) Boreal old-growth forest structural diversity challenges aerial photographic survey accuracy. Can J For Res. 50:155-169.

Table 6 Error-matrixes between the field and modern aerial surveys for the five clusters identified by multivariate analysis.

\begin{tabular}{cllllllll} 
Cluster & $\begin{array}{l}\text { Mield plots } \\
\text { Modern survey } \\
\text { old-growth class }\end{array}$ & Even-aged & Old-growth & Total & Even-aged & Old-growth & Total & $\begin{array}{c}\text { Overall } \\
\text { accuracy }\end{array}$ \\
\hline Cluster 1 & Even-aged & 0 & 8 & 8 & 0.0 & 47.1 & 47.1 & 52.9 \\
& Old-growth & 0 & 9 & 9 & 0.0 & 52.9 & 52.9 & \\
Total & 0 & 17 & 17 & 0.0 & 100.0 & 100.0 & \\
\hline Cluster 2 & Even-aged & 0 & 3 & 3 & 0.0 & 33.3 & 33.3 & 66.7 \\
Old-growth & 0 & 6 & 6 & 0.0 & 66.7 & 66.7 & \\
Total & 0 & 9 & 9 & 0.0 & 100.0 & 100.0 & \\
\hline Cluster 3 & Even-aged & 0 & 5 & 5 & 0.0 & 71.4 & 71.4 & 28.6 \\
& Old-growth & 0 & 2 & 2 & 0.0 & 28.6 & 28.6 & \\
& Total & 0 & 7 & 7 & 0.0 & 100.0 & 100.0 & \\
\hline Cluster 4 & Even-aged & 0 & 15 & 15 & 0.0 & 78.9 & 78.9 & 21.1 \\
Old-growth & 0 & 4 & 4 & 0.0 & 21.1 & 21.1 & \\
Total & 0 & 19 & 19 & 0.0 & 100.0 & 100.0 & \\
\hline Cluster 5 & Even-aged & 4 & 8 & 12 & 26.7 & 53.3 & 80.0 & 46.7 \\
& Old-growth & 0 & 3 & 3 & 0.0 & 20.0 & 20.0 & \\
Total & 4 & 11 & 15 & 26.7 & 73.3 & 100.0 &
\end{tabular}

\section{Discussion}

The results of the preindustrial and modern aerial surveys were often inconsistent. In particular, a large proportion of the undisturbed mature stands that were classified as old-growth in the preindustrial survey were classified as even-aged in the modern survey; clearly there is an error in one of the surveys. These changes occurred primarily in sparse pure black spruce stands. The comparison to field plot data clearly showed that the modern aerial survey underestimated the abundance of old-growth forests on the landscape with its accuracy decreasing with stand age, first cohort replacement and the reduction in tree species diversity. Differences in vertical and horizontal structures among even-aged, monospecific black spruce old-growth and mixed black spruce balsam fir old-growth stands may have also challenged the accuracy of the modern aerial survey. 
Aerial surveys underestimate boreal old-growth forest abundance and diversity

The lack of accuracy in the identification of boreal old-growth forests in the modern aerial survey was unexpected and worrying. This survey was performed during a period where the importance and relative abundance of old-growth forests was well known and the erosion of their abundance on the landscape in Eastern Canada was already identified as a major issue (Kneeshaw and Gauthier 2003). Thus, boreal old-growth forests were a contemporary management issue and we expected that modern survey would provide increased precision on their status and distribution over the landscape. In addition, boreal old-growth forests were probably abundant in the study territory, where the theoretical fire cycle over the last century ranges between 200 and 272 years (Gauthier, Raulier, et al. 2015; Couillard et al. 2016). In Eastern Canadian boreal forests, the onset of the old-growth stage may vary from one stand to another, but almost all stands that have not burned in the last 200 years present a complex vertical and horizontal structure (Martin et al. 2018). Thus, stands with a clearly complex structure should represent at least half of the productive landscape, even if recent fires and logging activities may have decreased their current abundance (Appendix E). Yet, the modern aerial survey identified only $5.8 \%$ of the productive forests and $19.4 \%$ of the productive mature stands as structurally old-growth. According to the low accuracy of the modern aerial survey in the identification of boreal oldgrowth forests on the study territory, it is therefore likely that most of the boreal old-growth forests were not identified.

Boreal old-growth forests were twice as abundant in the preindustrial vs. the modern aerial survey (respectively $49 \%$ and $19.4 \%$ of the centroids). This frequency is close to the theoretical old-growth frequency that can be estimated from the landscape disturbance regime (Appendix E). Yet, the accuracy of the preindustrial survey cannot be estimated with our field data because of the long time interval between the preindustrial survey and our field survey. The efficacy of the preindustrial aerial survey in identifying old-growth should be assessed with field surveys in future research projects, for example using the temporary and permanent field plots surveyed by the MFWP for each decadal forest survey, as it is possible that this survey was more accurate than the modern. Determining the preindustrial aerial survey error rate would also help to better identify the 
factors explaining the differences with the modern aerial survey. Moreover, the criteria used to define the old-growth stands changed between the two aerial surveys. In the preindustrial aerial survey, the qualification of structurally complex mature stands was based on the subjective determination of a strong variation in tree heights (Pelletier et al. 2007). In contrast, in the modern aerial survey old-growth stands were identified based on specific canopy cover thresholds of the cohort structure and the variation in tree height (MRNF 2008). As a consequence, these changes in the methodology of photointerpretation of forest structure may have caused a decrease in identifying accurately old-growth forests in our study area.

Aerial survey thresholds and indicators are irrelevant for boreal forests

Stands perceived as old-growth in the preindustrial aerial survey but as evenaged in the modern aerial were mainly sparse pure black spruce forests. Environments favouring pure black spruce stands at the end of succession in this region are often less productive than those favouring mixtures of black spruce and balsam fir (Messaoud et al. 2014; Martin et al. 2018; Portier et al. 2018). Moreover, a sparser canopy may indicate a low stand productivity caused by paludification or low-severity fires (Fenton et al. 2005; Smirnova et al. 2008). As a result, stands that shifted from an old-growth to an even-aged structure between the two surveys were probably defined by relatively low stand heights. Yet, to be classified as irregular, and therefore old-growth, by the modern aerial survey, tree height had to vary by at least $8 \mathrm{~m}$ for the irregular structure class or $5 \mathrm{~m}$ for the bi-cohort (this class however represented only $0.5 \%$ of the centroids). Such thresholds are relevant in biomes where trees get taller with age, leading to a complex vertical stratification of old-growth stands (Franklin et al. 2002). However, boreal old-growth forest characteristics often differ from those of old-growth forests from other biomes, because of the harsh climatic conditions that limit tree height and longevity (Bergeron and Harper 2009). Thus, many boreal old-growth forests may be erroneously identified as structurally even-aged because the thresholds used by the modern aerial survey require too large of a height differential. 
The difficulty in detecting structurally complex pure black spruce old-growth stands may be reinforced by their poorly stratified vertical structure. Indeed, for most of these stands, codominant, intermediate and suppressed trees represented an equal proportion of the canopy. In contrast, suppressed trees dominated the canopy of mixed black spruce - balsam fir old-growth stands. This stratification may result from balsam fir's greater sensitivity to spruce budworm outbreaks, root rot and windthrow, leading to higher mortality rates in comparison to black spruce (Ruel 2000; Morin et al. 2009). In contrast, the canopy of pure black spruce old-growth stands may have been perceived as vertically homogeneous, and then confounded with an even-aged canopy, resulting in their misclassification as "even-aged" stands. Thus, from an aerial perspective, stand vertical stratification was more visible for mixed black spruce - balsam fir oldgrowth stands than for pure black spruce.

Identifying pure black spruce old-growth stands can also be challenging because of the possible absence of tree species transition between the even-aged and oldgrowth stages. Indeed, because of its semi-serotinous cones and its layering ability, black spruce can either act as a pioneer or a late-successional species (Harvey et al. 2002). As a consequence, black spruce stands with no changes in tree species composition since the last stand-replacing disturbance are common in Eastern Canadian boreal forests driven by wildfires as stand-replacing disturbances (Harper et al. 2002; Martin et al. 2018). Consequently, differentiating several black spruce cohorts in old-growth stands is challenging, in particular from aerial photographs. In contrast, the position of the other tree species in forest succession is well defined. Therefore, it may be easier to identify the old-growth stage of stands containing tall and old pioneer species, like aspen, or late-successional species, like balsam fir, in comparison to monospecific black spruce stands.

Distinguishing an old-growth forest from an even-aged is difficult, because there is no clear shift between the two stages (Pesklevits et al. 2011). For the same reason, defining thresholds that discriminate even-aged and old-growth stands is also challenging. The combination of the Weibull's shape parameter and cohort basal area proportion to identify boreal old-growth forests has proven to be efficient (Martin et al. 2018) and represents the same cartographic structural 
attributes as those used by the modern aerial survey (i.e. increasing vertical complexity and progressive replacement of the first cohort). However, it is possible that field and aerial old-growth stage thresholds did not totally match, especially for the definition of the beginning of the old-growth stage. Consequently, we expected that stands inaccurately identified as even-aged by aerial surveys would have been mostly stands at the beginning of the old-growth transition. Nevertheless, stands at the beginning of the old-growth transition were grouped in the same cluster (Cluster 5). Only 20.5\% of the field plots identified as old-growth by the field survey but as even-aged by the modern aerial survey belonged to this cluster. Thus, the discrepancies observed between modern aerial and field surveys were not caused by a bias due to inconsistent old-growth thresholds but by the modern aerial survey inaccuracy, as most of these stands were unambiguously old-growth. Moreover, the field plots were $400 \mathrm{~m}^{2}$ in size, while forest polygons often have an area of several hectares. As a result, ground plots may not have been able to capture internal variability within a polygon. However, the polygons of the decadal forest inventories are supposed to represent homogeneous stands in terms of structure and age. In addition, we have mainly identified uneven-aged stands with complex structures in the field plots and very few regular even-aged stands. It seems unlikely that we have mainly sampled small old-growth residual forests within even-aged stands since site selection was random. While it is possible that the structure of old-growth boreal forests can be highly variable within the same stand, we think that the field inventories were able to determine whether the polygons sampled were old-growth or even-aged forests.

\section{Conclusion and management implication}

Boreal old-growth forests structural specificities challenged aerial survey accuracy, causing a significant underestimation of their abundance on the study territory. This error was reinforced by the standardization of Québec's decadal forest survey methodology for all the province. Modern survey thresholds and indicators were thus poorly adapted to boreal old-growth forests common structural attributes, i.e. a low tree height, the lack of clearly delineated canopy strata and the absence of any species transition between the even-aged and the old-growth stage. In contrast, the transition period between the even-aged and 
the old-growth stage had no influence on aerial survey accuracy, as the majority of the old-growth stands inaccurately identified as even-aged were true oldgrowth stands.

Pure black spruce old-growth stands were those that were the most confused with even-aged stands by the modern aerial survey. Yet, the majority of Québec's boreal forests become pure black spruce stands at the end of succession. Therefore, the majority of Québec's boreal forests may be erroneously identified as structurally even-aged by the modern aerial survey. Moreover, pure black spruce old-growth stands are not only abundant but also structurally diverse. Thus, the results of our study raise concerns about the capacity of forest management to maintain the preindustrial boreal landscape diversity as most boreal old-growth forests are not well identified by forest inventories.

The efficacy of photographic aerial surveys in identificatying and discriminating of complex forest structures has been questioned previously and the results of our study confirm these concerns. Therefore, new techniques should be used to accurately identify boreal old-growth forests (Chaieb et al. 2015). LiDAR (Light Detection And Ranging) technology is therefore a promising tool for a quick and efficient discrimination of stand structures (Kane et al. 2010; Jayathunga et al. 2018). In a change from the modern (fourth) aerial forest survey, the ongoing fifth decadal forest survey collects both photographic and LIDAR data, opening the way for a better identification of boreal old-growth forests. However, the efficacy of LIDAR-derived metrics to discriminate boreal old-growth and evenaged forests has not yet been demonstrated. As a consequence, future research must be performed to determine if the transition from aerial photographic to LIDAR surveys will improve the identification of boreal old-growth forests in managed landscapes.

\section{Acknowledgements}

We thank Audrey Bédard, Jean-Guy Girard, Émilie Chouinard, Miguel Montoro Girona, Anne-Élizabeth Harvey, Aurélie Cuvelière, Évelyn Beliën and Angelo Fierravanti for their precious help during field sampling. Yan Boucher and Pierre Grondin from the Québec's Ministry of Forests, Fauna and Parks (MFFP) shared 
their data collected from the study territory. We also thank the MFFP for sharing their surveys and disturbances database as well as two anonymous reviewers for their useful suggestions and comments on the previous version of the manuscript. Finally, we would like to thank Ellen Macdonald, Canadian Journal of Forest Research Co-Editor-in-Chief, for her judicious comments during manuscript finalization. Funding for this project was provided by the Fonds Québécois de la Recherche sur la Nature et les Technologies (FQRNT) and the Natural Sciences and Engineering Research Council of Canada (NSERC) - Université du Québec à Chicoutimi (UQAC) industrial research chair "Chaire de recherche industrielle du CRSNG sur la croissance de l'épinette noire et l'influence de la tordeuse des bourgeons de l'épinette sur la variabilité des paysages en zone boréale".

\section{References}

Angelstam P, Kuuluvainen T. 2004. Boreal Forest Disturbance Regimes , Successional Dynamics and Landscape Structures : A European Perspective. Ecol Bull.(51):117-136.

Bailey RL, Dell R. 1973. Quantifying Diameter Distributions with the Weibull Function. For Sci. 19(2):97-104.

Bauhus J, Puettmann K, Messier C. 2009. Silviculture for old-growth attributes. For Ecol Manage. 258(4):525-537. doi:10.1016/j.foreco.2009.01.053.

Bélisle AC, Gauthier S, Cyr D, Bergeron Y, Morin H. 2011. Fire Regime and Old-Growth Boreal Forests in Central Quebec , Canada: An Ecosystem Management Perspective. Silva Fenn. 45(November):889-908.

Bergeron Y, Fenton NJ. 2012. Boreal forests of eastern Canada revisited: old growth, nonfire disturbances, forest succession, and biodiversity. Botany. 90(6):509-523. doi:10.1139/b2012-034.

Bergeron Y, Harper KA. 2009. Old-growth forests in the Canadian boreal: the excep- tion rather than the rule? In: Wirth C, Gleixner G, Heimann M, editors. Old-Growth Forests: Function, Fate and Value. Ecological. New York: Springer. p. 285-300. 
BergeronY, Harvey B, Leduc A, Gauthier S. 1999. Forest management guidelines based on natural disturbance dynamics : Stand and forest-level considerations. For. Chron. 75: 49-54

Bergeron Y, Leduc A, Harvey A, Gauthier S. 2002. Natural fire regime: A guide for sustainable management of the Canadian boreal forest. Silva Fenn. 36: 8195.

Bergeron Y, Drapeau P., Gauthier S, Lecomte N. 2007. Using knowledge of natural disturbances to support sustainable For. Chron. 83: 326-337.

Blouin J, Berger J-P. 2004. Guide de reconnaissance des types écologiques Région écologique 6c (Plaine du lac Opémisca) - Région écologique 6d (Coteaux du lac Assinica) - Région écologique 6e (Coteaux de la rivière Nestaocano) Région écologique 6f (Coteaux du lac Mistassini). Ministère des Ressources naturelles, de la Faune et des Parcs, Forêt Québec, Direction des inventaires forestiers, Division de la classification écologique et productivité des stations.

Boucher D, De Grandpré L, Gauthier S. 2003. Développement d'un outil de classification de la structure des peuplements et comparaison de deux territoires de la pessière à mousses du Québec. For Chron. 79(2):318-328. doi:10.5558/tfc79318-2.

Boucher D, De Grandpré L, Kneeshaw D, St-Onge B, Ruel J-C, Waldron K, Lussier J-M. 2015. Effects of 80 years of forest management on landscape structure and pattern in the eastern Canadian boreal forest. Landsc Ecol.(30):1913-1929. doi:10.1007/s10980-015-0220-6.

Boucher Y, Perrault-Hébert M, Fournier R, Drapeau P, Auger I. 2017. Cumulative patterns of logging and fire (1940-2009): consequences on the structure of the eastern Canadian boreal forest. Landsc Ecol. 32(2):361-375. doi:10.1007/s10980-016-0448-9.

Boudreault C, Paquette M, Fenton NJ, Pothier D, Bergeron Y. 2018. Changes in bryophytes assemblages along a chronosequence in eastern boreal forest of Quebec. Can J For Res. 48(7):821-834. doi:10.1139/cjfr-2017-0352. 
Chaieb C, Fenton NJ, Lafleur B, Bergeron Y. 2015. Can We Use Forest Inventory Mapping as a Coarse Filter in Ecosystem Based Management in the Black Spruce Boreal Forest? Forests, 6(4), 1195-1207. https://doi.org/10.3390/f6041195

Côté G, Bouchard M, Pothier D, Gauthier S. 2010. Linking stand attributes to cartographic information for ecosystem management purposes in the boreal forest of eastern Québec. For Chron. 86(4):511-519. doi:10.5558/tfc86511-4.

Couillard P-L, Frégeau M, Payette S, Grondin P, Lavoie M, Laflamme J. 2016. Dynamique et variabilité naturelle de la pessière à mousses au nord de la région du Lac-Saint-Jean. Québec.

Cyr D, Bergeron Y, Gauthier S, Larouche AC. 2005. Are the old-growth forests of the Clay Belt part of a fire-regulated mosaic? Can J For Res. 35(1):65-73. doi:10.1139/x04-204.

De'ath G. 2002. Multivariate Regression Trees: A New Technique for Modeling Species-Environment Relationships. Ecology. 83(4):1105-1117.

Drapeau P, Nappi A, Imbeau L, Saint-Germain M. 2009a. Standing deadwood for keystone bird species in the eastern boreal forest: Managing for snag dynamics. The For. Chron. 85: 227-234.

Drapeau P, Leduc A, Bergeron Y. 2009b. Bridging ecosystem and multiple species approaches for setting conservation targets in managed boreal landscapes. Chapter 7 In M-A Villard and B-G Jonsson (editors). Setting conservation targets in managed forest landscapes, pp. 129-160. Cambridge University Press, Cambridge.

Drapeau P, Villard M-A, Leduc A, Hannon SJ. 2016. Natural disturbance regimes as templates for the response of bird species assemblages to contemporary forest management. Divers Distrib. 22: 385-399.

Fenton NJ, Lecomte N, Légaré S, Bergeron Y. 2005. Paludification in black spruce (Picea mariana) forests of eastern Canada: Potential factors and management implications. For Ecol Manage. 213(1-3):151-159. doi:10.1016/j.foreco.2005.03.017. 
Franklin JF, Lindenmayer DB, Thornburgh D a, Pelt R Van, Chen J, Spies T a, Carey AB, Shaw DC, Berg DR, Harmon ME, et al. 2002. Disturbances and structural development of natural forest ecosystems with silvicultural implications, using Douglas-fir forests as an example. For Ecol Manage. 155:399423. doi:10.1016/S0378-1127(01)00575-8.

Gauthier S, Bernier P, Kuuluvainen T, Shvidenko AZ, Schepaschenko DG. 2015. Boreal forest health and global change. Science (80- ). 349(6250):819-822. doi:10.1126/science.aac6759.

Gauthier S, Raulier F, Ouzennou H, Saucier J-P. 2015. Strategic analysis of forest vulnerability to risk related to fire: an example from the coniferous boreal forest of Quebec. Can J For Res. 45(5):553-565. doi:10.1139/cjfr-2014-0125.

Gauthier S, Vaillancourt M-A, Kneeshaw DD, Drapeau P, Grandpré L De, Claveau Y, Paré D. 2009. Forest ecosystem management, origins and foundations. In: Gauthier S, Vaillancourt M-A, Leduc A, Grandpré L De, Kneeshaw DD, Grandpré L De, Morin H, Drapeau P, Bergeron Y, editors. Ecosystem Management in the Boreal Forest. Montréal: Presses de l'Université du Québec. p. 13-18.

Grandpré L De, Gauthier S, Allain C, Cyr D, Périgon S, Pham AT, Boucher D, Morissette J, Reyes G, Aakala T, et al. 2009. Towards an ecosystem approach to managing the boreal forest in the North Shore Region: disturbance regime and natural forest dynamics. In: Ecosystem management in the boreal forest. 1st editio. Québec: Presses de l'Université du Québec. p. 229-255.

Harper KA, Bergeron Y, Gauthier S, Drapeau P. 2002. Post-fire development of canopy structure and composition in black spruce forests of Abitibi, Quebec: A landscape scale study. Silva Fenn. 36(1):249-263.

Harvey BD, Leduc A, Gauthier S, Bergeron Y. 2002. Stand-landscape integration in natural disturbance-based management of the southern boreal forest. For Ecol Manage. 155(1-3):369-385. doi:10.1016/S0378-1127(01)00573-4.

Jayathunga S, Owari T, Tsuyuki S. 2018. Analysis of forest structural complexity 
using airborne LiDAR data and aerial photography in a mixed conifer-broadleaf forest in northern Japan. J For Res. 29(2):479-493. doi:10.1007/s11676-017-04414 .

Kane VR, McGaughey RJ, Bakker JD, Gersonde RF, Lutz JA, Franklin JF. 2010. Comparisons between field- and LiDAR-based measures of stand structural complexity. Can J For Res. 40(4):761-773. doi:10.1139/X10-024.

Kneeshaw D, Gauthier S. 2003. Old growth in the boreal forest: A dynamic perspective at the stand and landscape level. Environ Rev. 11(S1):S99-S114. doi:10.1139/a03-010.

Kuuluvainen T. 2009. Forest Management and Biodiversity Conservation Based on Natural Ecosystem Dynamics in Northern Europe: The Complexity Challenge. Ambio. 38(6):309-315.

Lüdecke D. 2018. sjstats: Statistical Functions for Regression Models.

Marshall PL, Davis G, LeMay VM. 2000. Using Line Intersect Sampling for Coarse Woody Debris. Nanaimo, British Columbia, Canada.

Martin M, Fenton NJ, Morin H. 2018. Structural diversity and dynamics of boreal old-growth forests case study in Eastern Canada. For Ecol Manage. 422(April):125-136. doi:10.1016/j.foreco.2018.04.007.

Martin M, Morin H, Fenton NJ. Accepted. Secondary disturbances of low and moderate severity drive the dynamics of Eastern Canadian boreal old-growth forests. Ann For. Sci.

Messaoud Y, Asselin H, Bergeron Y, Grondin P. 2014. Competitive Advantage of Black Spruce Over Balsam Fir in Coniferous Boreal Forest of Eastern North America Revealed by Site Index. For Sci. 60(1):57-62.

Morin H, Laprise D, Simon AA, Amouch S. 2009. Spruce budworm outbreak regimes in in eastern North America. In: Gauthier S, Vaillancourt M-A, Leduc A, Grandpré L De, Kneeshaw DD, Morin H, Drapeau P, Bergeron Y, editors. Ecosystem management in the boreal forest. Québec: Les Presses de l'Université 
du Québec. p. 156-182.

Moussaoui L, Leduc A, Fenton NJ, Lafleur B, Bergeron Y. 2019. Changes in forest structure along a chronosequence in the black spruce boreal forest: Identifying structures to be reproduced through silvicultural practices. Ecol Indic. 97(October 2018):89-99. doi:10.1016/j.ecolind.2018.09.059.

[MRNF] Ministère des Ressources Naturelles et de la Faune du Québec. 2008. Norme de stratification écoforestière. Quatrième inventaire forestier. Québec: Direction des inventaires forestiers.

Nakazawa M. 2017. fmsb: Functions for Medical Statistics Book with some Demographic Data.

Oksanen J, Blanchet G, Friendly M, Kindt R, Legendre P, MCGlinn D, Minchin PRB, O'Hara B, Simpson GL, Solymos P, et al. 2018. vegan: Community Ecology Package.

Olofsson P, Foody GM, Stehman S V., Woodcock CE. 2013. Making better use of accuracy data in land change studies: Estimating accuracy and area and quantifying uncertainty using stratified estimation. Remote Sens Environ. 129:122-131. doi:10.1016/j.rse.2012.10.031.

Östlund L, Zackrisson O, Axelsson a-L. 1997. The history and transformation of a Scandinavian boreal forest landscape since the 19th century. Can J For Res. 27(8):1198-1206. doi:10.1139/x97-070.

Patry C, Kneeshaw D, Aubin I, Messier C. 2017. Intensive forestry filters understory plant traits over time and space in boreal forests. Forestry. 90(3):436444. doi:10.1093/forestry/cpx002.

Pelletier G, Dumont Y, Bédard M. 2007. SIFORT: Système d'Information Forestière par Tessel. Québec.

Pesklevits A, Duinker PN, Bush PG. 2011. Old-growth forests: Anatomy of a wicked problem. Forests. 2(1):343-356. doi:10.3390/f2010343. 
Portier J, Gauthier S, Cyr G, Bergeron Y. 2018. Does time since fire drive live aboveground biomass and stand structure in low fire activity boreal forests? Impacts on their management. J Environ Manage. 225(April):346-355. doi:10.1016/j.jenvman.2018.07.100.

Robitaille A, Saucier J-P. 1998. Paysages régionaux du Québec méridional. Montréal: Les Publications du Québec.

Rowe JS. 1972. Forest regions of Canada. Ottawa, Ont., Canada: Canadian Forest Service, Department of Fisheries and the Environment.

Ruel J. 2000. Factors influencing windthrow in balsam fir forests : from landscape studies to individuel tree studies. For Ecol Manage. 135(135):169-178.

Sheskin DJ. 2002. Handbook of parametric and nonparametric statistical procedures. Second edi. Chapman \& Hall/CRC, editor. Boca Raton, FL.

Shorohova E, Kneeshaw D, Kuuluvainen T, Gauthier S. 2011. Variability and Dynamics of Old- Growth Forests in the Circumboreal Zone: Implications for Conservation, Restoration and Management. Silva Fenn. 45(5):785-806.

Sing T, Sander O, Beerenwinkel N, Lengauer T. 2005. ROCR: visualizing classifier performance in R. Bioinformatics. 21(20):78881.

Smirnova E, Bergeron Y, Brais S. 2008. Influence of fire intensity on structure and composition of jack pine stands in the boreal forest of Quebec: Live trees, understory vegetation and dead wood dynamics. For Ecol Manage. 255:29162927. doi:10.1016/j.foreco.2008.01.071.

Therneau TM, Atkinson B. 2014. mvpart: Multivariate partitioning.

Tikkanen OP, Martikainen P, Hyvarinen E, Junninen K, Kouki J. 2006. Redlisted boreal forest species of Finland: associations with forest structure, tree species, and decaying wood. Ann Zool Fennici. 43(4):373-383. doi:https://doi.org/10.1073/pnas.87.3.1139.

Tjur T. 2009. Coefficients of determination in logistic regression models - A new 
Preprint Martin et al. (2020) Boreal old-growth forest structural diversity challenges aerial photographic survey accuracy. Can J For Res. 50:155-169.

proposal: The coefficient of discrimination. Am Stat. 63(4):366-372. doi:10.1198/tast.2009.08210.

Van Wagner CE. 1978. Age-class distribution and the forest fire cycle. Can J Restor. 8(1):220-227. doi:10.1007/s13398-014-0173-7.2.

Zweig MH, Campbell G. 1993. Receiver-oprating characteristics (ROC) plots - a fundamental evaluation tool in clinical medicine. Clin Chem. 39(4):561-577. doi:ROC; Receiver-Operating Characteristic; SDT; Signal Detection Theory. 
Preprint Martin et al. (2020) Boreal old-growth forest structural diversity challenges aerial photographic survey accuracy. Can J For Res. 50:155-169.

\section{Supplementary materials}

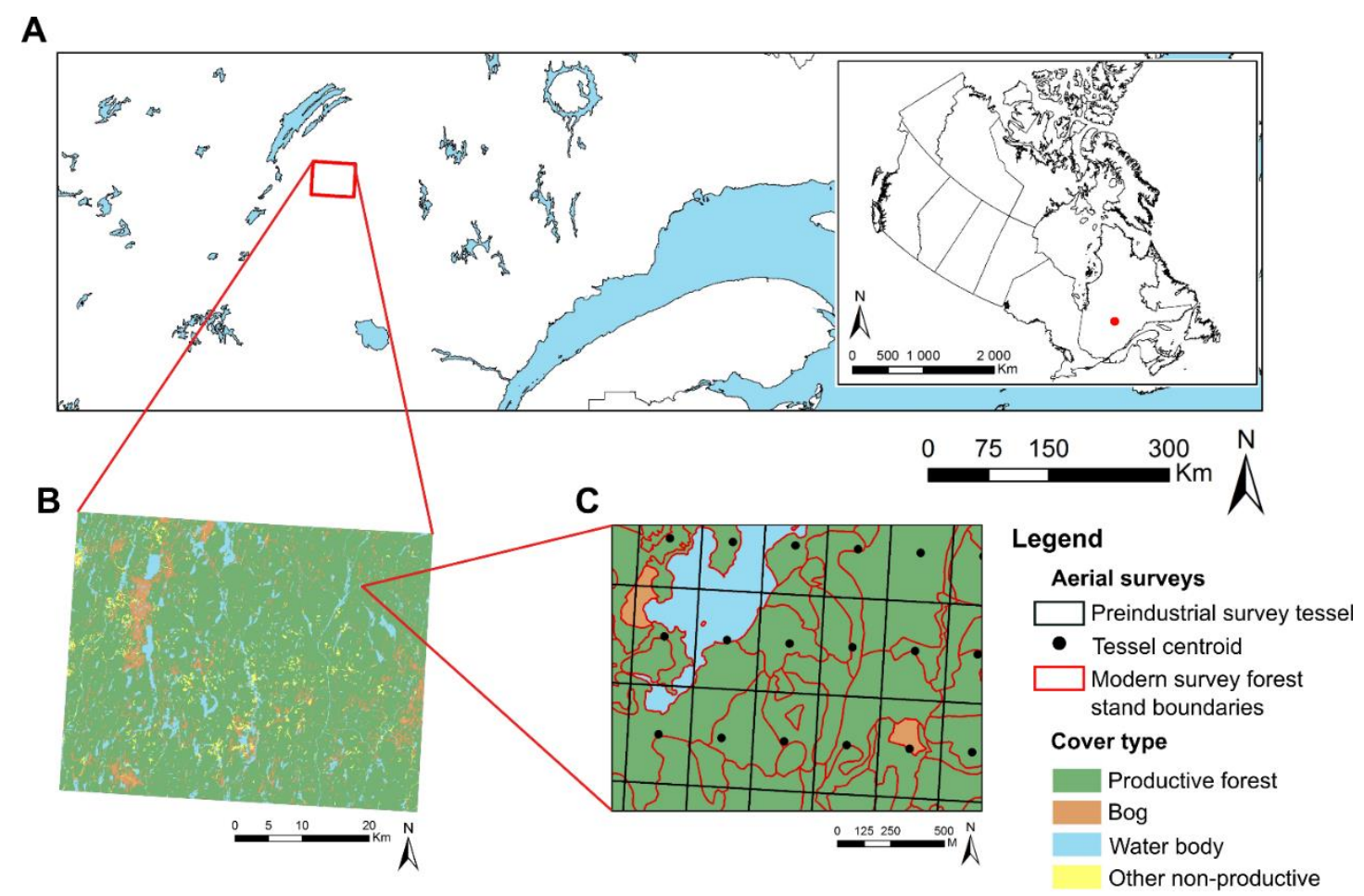

Appendix A A: Location of the study territory in the province of Québec. The insert map represents its location in Canada. B: Spatial distribution of the main cover types in the study territory. C: Example of preindustrial aerial survey tessels and modern aerial survey forest stands' boundaries. 


\section{[Tapez ici]}

\begin{tabular}{|c|c|c|c|c|c|c|c|}
\hline Parameter & Acronym & Unit & Description & Mean & Std.error & Minimum & Maximum \\
\hline Tree density & TD & $\mathrm{n} / \mathrm{ha}$ & Number of living merchantable stems per hectare & 922.97 & 384.48 & 50.00 & 1875.00 \\
\hline Sapling density & SD & $\mathrm{n} / \mathrm{ha}$ & Number of living saplings per hectare & 2630.74 & 1933.76 & 275.00 & 10950.00 \\
\hline Basal area & BA & $\mathrm{m}^{2} / \mathrm{ha}$ & Basal area of the living merchantable trees per hectare & 17.53 & 7.53 & 0.37 & 35.45 \\
\hline $\begin{array}{l}\text { Basal fir } \\
\text { proportion }\end{array}$ & BFP & $\%$ & Proportion of balsam fir in the basal area & 12.53 & 21.54 & 0.00 & 94.64 \\
\hline $\begin{array}{l}\text { Coarse woody } \\
\text { debris volume }\end{array}$ & CWD & $\mathrm{m}^{3} / \mathrm{ha}$ & $\begin{array}{l}\text { Calculated according to the Marshall et al. (2000) formula for linear coarse woody } \\
\text { debris sampling: }\end{array}$ & 58.65 & 52.36 & 0.00 & 197.01 \\
\hline Gap fraction & GF & $\%$ & Mean value of the five gap fraction results at each site & 62.82 & 25.42 & 20.88 & 100.00 \\
\hline $\begin{array}{l}\text { Maximum } \\
\text { height }\end{array}$ & MH & $\mathrm{m}$ & Mean height value of the dominant trees sampled at each site & 18.49 & 3.17 & 7.90 & 24.40 \\
\hline $\begin{array}{l}\text { Weibull's shape } \\
\text { parameter }\end{array}$ & WSP & - & $\begin{array}{l}\text { Calculated using the Weibull's function of diameter distribution (Bailey and Dell } \\
\text { 1973), defined by the following equation for a random variable X: } \\
\qquad f(x)=\left(\frac{a}{b}\right) \times\left(\frac{x}{b}\right) \times \exp \left\{-(x / b)^{a}\right\} ; x \geq 0 ; a>0 ; b>0 \\
\text { This equation is characterized by the shape parameter } a \text {, identified in our study as } \\
\text { the Weibull's shape parameter (WSP), and the scale parameter } b \text {. } \\
\text { WSP } \geq 1.5 \text { represent a Gaussian distribution of the diameters, } 1 \leq \mathrm{WSP}<1.5 \text { an } \\
\text { irregular distribution and WSP }<1 \text { a reverse J-shaped distribution }\end{array}$ & 1.05 & 0.45 & 0.07 & 2.76 \\
\hline Shannon index & SI & - & $\begin{array}{l}\text { Calculated according to the Shannon diversity index formula (Shannon and Weaver } \\
\text { 1949) with basal area abundance rather than individual abundance }\end{array}$ & 0.14 & 0.14 & 0.00 & 0.46 \\
\hline $\begin{array}{l}\text { Cohort basal } \\
\text { area proportion }\end{array}$ & CBAP & - & $\begin{array}{l}\text { Proportion of } \mathrm{N}+1 \text { trees in the basal area, calculated using the Kneeshaw and } \\
\text { Gauthier (2003) formula: } \\
\qquad C B A P=\frac{\left(B A_{N} 1 \text { trees }+0.1\right)}{\left(B A_{N+1} \text { trees }+0.1+B A_{\text {First cohort trees })}\right.}\end{array}$ & 0.57 & 0.37 & 0.06 & 1.00 \\
\hline $\begin{array}{l}\text { Minimum time } \\
\text { since last fire }\end{array}$ & MTSLF & years & Maximum age value among the ten basal discs & 195.81 & 62.53 & 89.00 & 307.00 \\
\hline
\end{tabular}

Appendix B Description of the field structural attributes computed from the field surveys and summary statistics. 
Preprint Martin et al. (2020) Boreal old-growth forest structural diversity challenges aerial photographic survey accuracy. Can J For Res. 50:155-169.

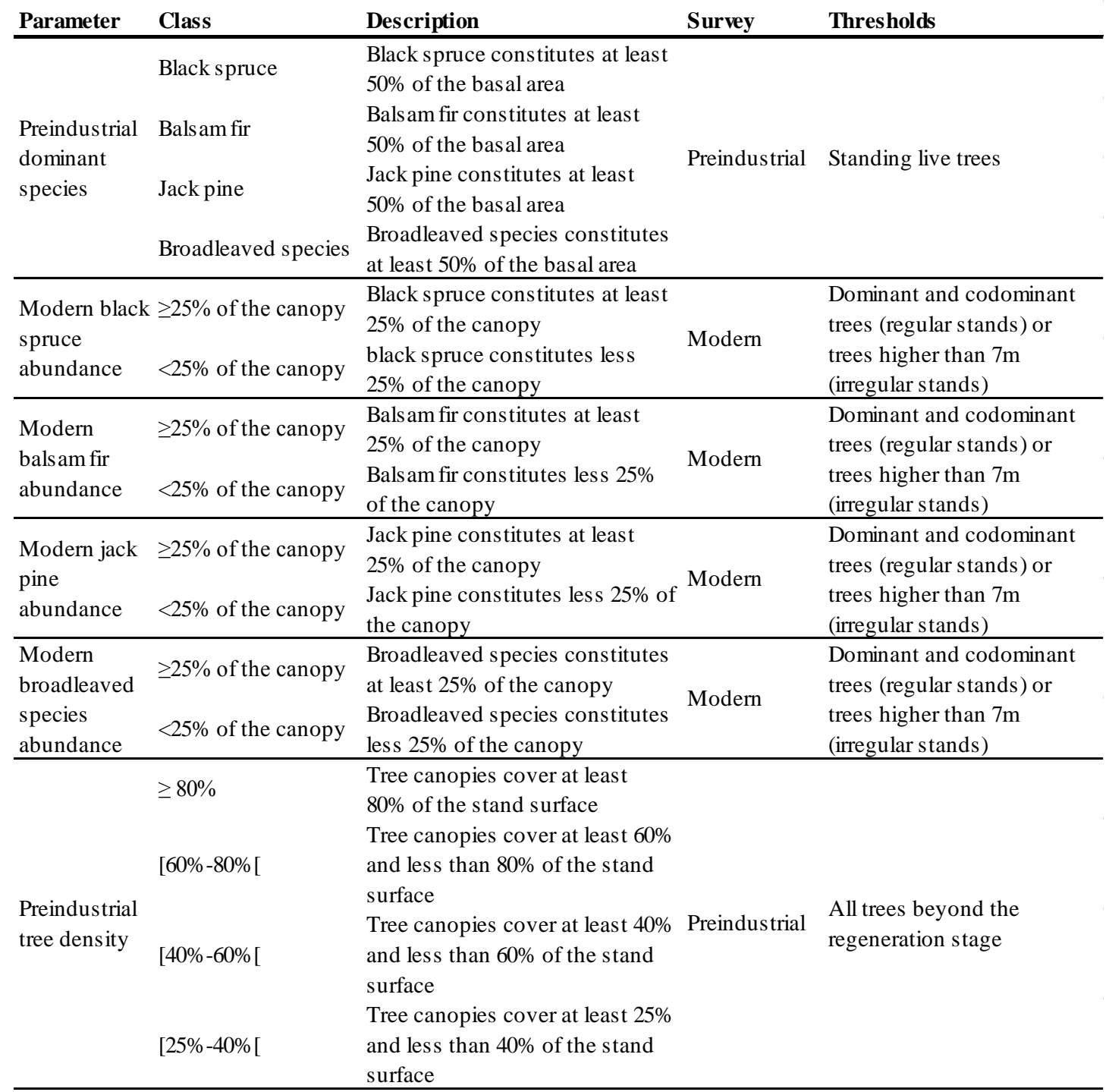

Appendix C Description of the cartographic structure attributes computed for the centroids $(1 / 2)$. 
Preprint Martin et al. (2020) Boreal old-growth forest structural diversity challenges aerial photographic survey accuracy. Can J For Res. 50:155-169.

\begin{tabular}{|c|c|c|c|c|}
\hline Parameter & Class & Description & Survey & Thresholds \\
\hline $\begin{array}{l}\text { Modern tree } \\
\text { density }\end{array}$ & $\begin{array}{l}\geq 80 \% \\
{[60 \%-80 \%[} \\
{[40 \%-60 \%[} \\
{[25 \%-40 \%[}\end{array}$ & $\begin{array}{l}\text { Tree canopies cover at least } \\
80 \% \text { of the stand surface } \\
\text { Tree canopies cover at least } 60 \% \\
\text { and less than } 80 \% \text { of the stand } \\
\text { surface } \\
\text { Tree canopies cover at least } 40 \% \\
\text { and less than } 60 \% \text { of the stand } \\
\text { surface } \\
\text { Tree canopies cover at least } 25 \% \\
\text { and less than } 40 \% \text { of the stand } \\
\text { surface }\end{array}$ & Modern & $\begin{array}{l}\text { Dominant and codominant } \\
\text { trees (regular stands) or } \\
\text { trees higher than } 7 \mathrm{~m} \\
\text { (irregular stands) }\end{array}$ \\
\hline $\begin{array}{l}\text { Preindustrial } \\
\text { tree height }\end{array}$ & $\begin{array}{l}\geq 21 \mathrm{~m} \\
{[15-21 \mathrm{~m}[} \\
{[9-15 \mathrm{~m}[} \\
<9 \mathrm{~m}\end{array}$ & $\begin{array}{l}\text { Mean height of dominant and } \\
\text { codominant trees } \geq 21 \mathrm{~m} \\
\text { Mean height of dominant and } \\
\text { codominant tree between } 15 \text { and } \\
21 \mathrm{~m} \\
\text { Mean height of dominant and } \\
\text { codominant tree between } 9 \text { and } \\
15 \mathrm{~m} \\
\text { Mean height of dominant and } \\
\text { codominant tree }<9 \mathrm{~m}\end{array}$ & Preindustrial & $\begin{array}{l}\text { Dominant and codominant } \\
\text { trees }\end{array}$ \\
\hline $\begin{array}{l}\text { Modern tree } \\
\text { height }\end{array}$ & $\begin{array}{l}{[7-12 \mathrm{~m}[} \\
<7 \mathrm{~m}\end{array}$ & $\begin{array}{l}\text { Mean height of dominant and } \\
\text { codominant trees } \geq 22 \mathrm{~m} \\
\text { Mean height of dominant and } \\
\text { codominant tree between } 17 \text { and } \\
22 \mathrm{~m} \\
\text { Mean height of dominant and } \\
\text { codominant tree between } 12 \text { and } \\
17 \mathrm{~m} \\
\text { Mean height of dominant and } \\
\text { codominant tree between } 7 \text { and } \\
12 \mathrm{~m} \\
\text { Mean height of dominant and } \\
\text { codominant tree }<7 \mathrm{~m}\end{array}$ & Modern & $\begin{array}{l}\text { Dominant and codominant } \\
\text { trees }\end{array}$ \\
\hline
\end{tabular}

Appendix C Description of the cartographic structure attributes computed for the centroids $(2 / 2)$. 
Preprint Martin et al. (2020) Boreal old-growth forest structural diversity challenges aerial photographic survey accuracy. Can J For Res. 50:155-169.

Resid. Df Resid. Dev Df Deviance $\operatorname{Pr}(>\mathrm{Chi})$ AUC COD Parameter

Df Deviance Resid. Df Resid. Dev $\operatorname{Pr}(>\mathrm{Chi})$

31614285.2

$-5474.88$

$<0.001 \quad 0.71 \quad 0.14$ Mod. balsam fir abund.

Preindus. tree density

1293.1

31603992.1

$<0.001$

Modern tree density

31583835.8

$<0.001$

225.5

31563810.3

$<0.001$

Appendix D Results of the logistic regression final model comparing the frequency of centroids according to their structural evolution between the preindustrial and modern surveys (i.e. Consistent or Inconsistent).. Mod.: modern, Abund.: abundance, Preindus.: preindustrial. 
Preprint Martin et al. (2020) Boreal old-growth forest structural diversity challenges aerial photographic survey accuracy. Can J For Res. 50:155-169.

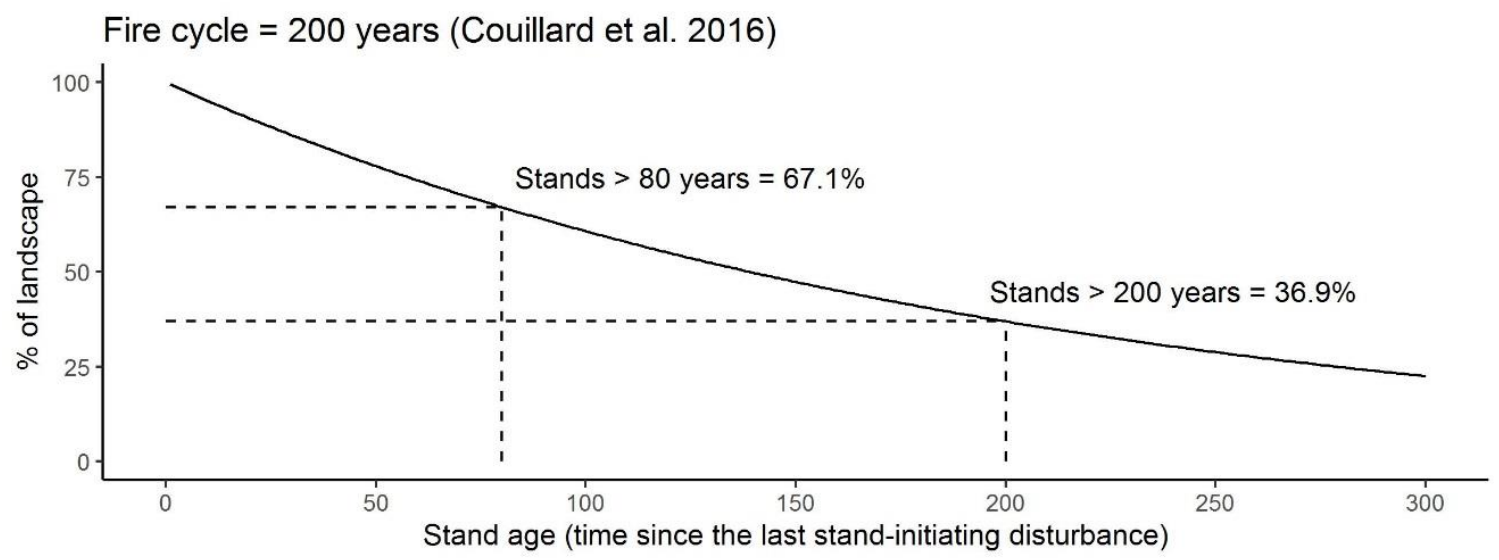

Fire cycle $=272$ years (Gauthier et al. 2015)

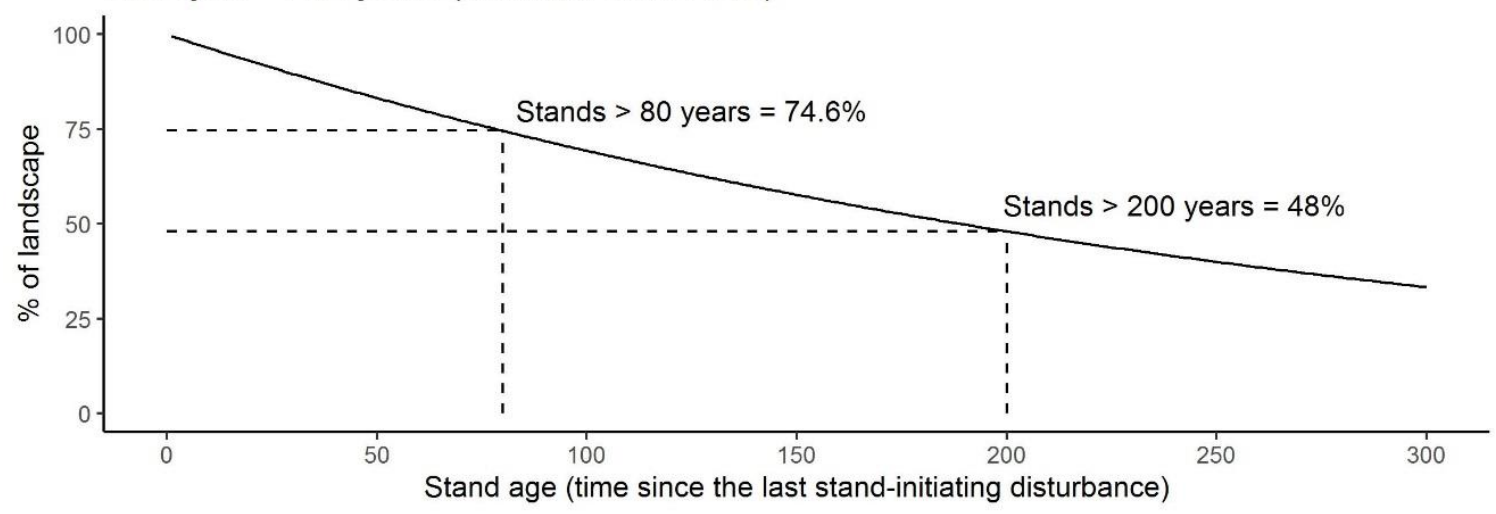

Appendix E Estimated landscape-age structure on the study territory according to the fire cycles estimated by Couillard et al. (2016) and Gauthier et al. (2015) using the Van Wagner (1978) formula. 